and figures from the first undergraduate classes admitted without affirmative action and on related congressional action follow.

- Only 98 African-American students have accepted invitations to enroll in the University of California, Berkeley's Class of 2002 this fall. Overall, 8,000 students were offered admission to the flagship school of the UC System, and 3,660 accepted. Neither the number nor percentage of Asian-American students offered or accepting admission declined in 1998.

- UC-Riverside admitted $42 \%$ more African-American students, and $52 \%$ more Mexican-American students, in 1998 than it did in 1997.

- The University of Texas at Austin offered admission to $6 \%$ more African-American and Hispanic students in 1998 than it did it 1997.

- U.S. Representative Frank Riggs's (R-CA) amendment to the Reauthorization of the Higher Education Act of 1965 bill, which would have prohibited any school that participates in HEA-authorized programs from using racial and gender perferences in making admissions decisions, was defeated on the House floor 171-249 in a vote that crossed party lines.

Compiled from Comments, bimonthly publication of the Conference on Professionals in Science and Technology.

\section{Publication of Foreign Relations of the United States Likely to Be Delayed}

The failure of several U.S. intelligence agencies, especially the Central Intelligence Agency, to meet legal requirements to fully and rapidly declassify thirty-year old documents related to U.S. foreign policy will cause delays in the publication schedule of Foreign Relations of the United States, warned the State Department Advisory Committee on Historical Diplomatic Documentation.

The committee, made up of academics and representatives of organizations with an interest in the his-

\section{Washington Insider}

Census 2000 Update: "Keep 'Long Form'" Urge Panelists Panelists testifying before a May meeting of the Census Committee of the House Committee on Government Reform and Oversight voiced almost unanimous support for continued use of the "long form" questionnaire in the upcoming Census. Representatives of groups as diverse as the American Legion, the Arab American Institute, and the National Association of Home Builders urged the Subcommittee overseeing the 2000 Census to prepare and distribute a long form questionnaire, as has been used in all previous Censuses, because data collected through its use "is the foundation of sound decision making in virtually every sector of our economy." Positive action on the long form is highly likely.

\section{Establishment of Federal Statistics Service Considered} The House Subcommittee on Government Management, Information and Technology held hearings in March on a Senate proposal to establish a commission to consolidate the Bureau of Labor Statistics, the Bureau of the Census, and the Bureau of Economic Analysis into an independent Federal Statistics Service. The consolidation has been proposed in light of widespread criticisms that the U.S. government's data collection, analysis, and distribution efforts are too scattered, too duplicative, and too costly. Social scientists invited to give testimony on the proposal voiced cautious support, but warned that any centralized government statistical agency would have a difficult time establishing and maintaining its nonpartisan identify.

\section{House Passes Copyright Term Extension Legislation}

In March, the House approved legislation that extends the length of copyright protection by 20 years for new and currently published works. The Senate will not take up this bill until after it settles debates over several Internet and database copyright bills, which means the bill will probably be shelved until 1999. Current copyright laws vest copyright in individual authors for their natural life plus 75 years and in corporate authors for 75 years.

\section{NARA Publishes Teaching Resource for Women's} Pre-Enfranchisement Participation in U.S. Politics The National Archives and Records Administration has published Our Mothers Before Us: Women and Democracy, 1789-1920, a collection of petitions written and sent to Congress by women in the preenfranchisement period. The collection is a fully developed teaching aid, complete with sample exercises and syllabi, and is the second in a series of such teaching aids prepared by NARA from their unique collection. Individual copies of Our Mothers Before Us may be purchased from the National Archives Bookstore (1-800-234-8861) for $\$ 59.95$, plus $\$ 5.00$ shipping and handling. 